\title{
THE LAMINAR PATTERN OF THE LATERAL GENICULATE BODY IN THE PRIMATES
}

\author{
BY \\ L. W. CHACKO \\ From the Department of Anatomy, University of Oxford
}

(RECEIVED JANUARY 22, 1948)

In the past the lateral geniculate body has tended to receive less than its due share of attention in the investigation of the neural basis of vision. Yet a detailed study of the intermediate cell station in the lateral geniculate body is clearly an essential part of such an investigation. The anatomical situation of the nucleus renders it difficult of direct experimental approach, and our present knowledge of it still rests largely on elementary anatomical methods.

The stratified structure of the lateral geniculate body is well known, and in the higher Primates it may consist of as many as six laminæ. The termination of crossed and uncrossed optic nerve fibres in alternate laminæ is also well established. Brouwer and Zeeman $(1925,1926)$ worked out a gross quadrantic projection of the retina in the nucleus by the application of the Marchi technique, and the details of this projection were further elucidated by Le Gros Clark and Penman (1934) by the study of transneuronal degeneration following small localized retinal lesions. Little, however, is yet known of the significance of the laminar disposition in different parts of the nucleus. Some misunderstanding in the past regarding the form and folding of the geniculate laminæ has evidently resulted from the difficulty of interpreting individual sections cut in different planes. For instance, in the human lateral geniculate body, a section in one plane gives the appearance of "inversion" of the laminæ, with the large cell laminæ forming the outermost layer, in another plane a pattern of " eversion" may be seen, and in a third plane both eversion and inversion become evident. So, also, the number of laminæ may appear to vary according to the plane in which the section is taken. Hence it becomes necessary to make reconstruction models so that the intranuclear differentiation and disposition of all the layers can be easily visualized.
Thuma (1928) adopted this method in his study of cat's lateral geniculate body, as also did Balado and Franke (1937) in their comprehensive work on the human geniculate body. Le Gros Clark did the same for Macaca mulatta (1941). This method further clarifies the relation of the nucleus to the surrounding neural structures, and facilitates the mapping of the projection fields of the retina. The significance of changes in the laminar pattern in a phylogenetic series can also be studied. Above all it affords an opportunity for a comparative study of the anatomical basis of the binocular and monocular representation fields, the central and peripheral vision fields, and changes in the lateral geniculate body associated with incomplete or hemi-decussation of optic nerve fibres.

\section{Materials and Methods}

Wax reconstruction models were made of the lateral geniculate body of Man, Lemur fulvus (brown lemur), and Microcebus murinus (mouse lemur). In the case of the human brain, a block of tissue containing the right lateral geniculate body was embedded in paraffin, and serial sections ( $10 \mu$ in thickness) were cut transiversely to the axis of the optic tract. The sections were stained with Borell's methylene blue. The outline of the nucleus and its laminæ in every fifth section (out of a total of 835) was traced with a projection apparatus at a magnification of 30 diameters and a model reconstructed by the blottingpaper and beeswax method. Serial sections of the lateral geniculate body of the brown lemur were cut $(15 \mu)$ in the long axis of the optic tract (which ascends to reach the lower end of the body and spreads over its outer surface). Tracings of every third section (out of a total of 300) were made at a magnification of 50 diameters. The same procedure was repeated on serial coronal sections $(15 \mu)$ of the lateral geniculate body of Microcebus murinus, cut in the long axis of the optic tract ; tracings of every other section (out of a total of 186) under a magnification of 50 diameters were made for the reconstruction of the model. 
I am indebted to Professor Le Gros Clark for the reconstruction model of the geniculate nucleus of Macaca mulatta and the serial sections used for prepariug the model, as well as for other material prepared by him during his previous work on the subject.

In order to facilitate the observations on the intranuclear laminar pattern after the models were completed, and also the task of their description, they were mounted in detachable blocks the boundaries of which were located approximately at points of maximum change in internal pattern at different levels. This type of construction permits an examination of the way in which a particular internal pattern in one local region passes into a different pattern in the adjacent region. The model of the human lateral geniculate body was mounted in seven blocks. The " pregeniculate" body, which is not in structural continuity with the main nucleus, was fixed in its correct position in relation to the most rostral section by a strip of metal plate. The model of the lateral geniculate body of Lemur fulvus was mounted in four blocks and that of Microcebus in two. In order to estimate the relative positions and proportions of largecelled and small-celled elements on the models, the areas of distribution of these two elements were painted in two different colours.

\section{Descriptive Observations}

Human Lateral Geniculate Body.-The form of the lateral geniculate body in Man was first described in 1905 by von Monakow. According to him it consists of the main part (Haupt-teil or Teil des Hilus), a lateral horn (Sporn Anteil), and an anterior part where the fibres of the optic tract enter the nucleus (Retina Anteil). In 1918 Winkler described it as consisting of the Kopf des Ganglion or the caput and the Sporn or cauda. In 1937 Balado and Franke described the form of the lateral geniculate body with the help of a reconstruction model. They described it as having an oval form, the long axis of which runs from before backwards, but they pointed out that their description did not tally with the classical description of Monakow and Winkler. It is, however, difficult to understand the illustrations they give of their model, for the latter shows very little correspondence with the well-recognized shape and proportions of the human geniculate body.

The form of the human lateral geniculate body as demonstrated by our model may be briefly described as follows (see Figs. 2, 3, and 4). It consists of : (1) a thick, prominent main part with a shallow " hilum" ventrally and a dorsal convexity rising to a prominent antero-posterior crest, and (2) a lateral flange-like extension, or lateral horn, curving laterally with its lateral free margin tipped upwards. The smail rounded eminence seen in the course of the optic tract in the gross dissection of the base of the brain, which in descriptive anatomy is usually designated as the "lateral geniculate body," is really the ventral convex surface of the lateral horn.
There is no symmetry of form on either side of the dorsal crest. Laterally, the dorsal surface of the main part slopes down abruptly to an irregular sulcus which marks it off from the lateral horn. Medial to the crest the dorsal surface presents different features at different levels. The anterior third of this surface is extremely uneven, the laminæ being here broken up into irregular projections by the sweeping entrance of the optic tract fibres. Some of the irregularities are so prominent that Balado and Franke have described them as special "Spornen." This region corresponds to the "Retina Anteil" of Monakow. In the middle third the dorsal surface slopes very gradually from the dorsal crest to terminate medially in an incurved blunt rounded " medial tubercle." In the posterior third the medial surface slopes abruptly from the crest and continues into the posterior end of the concavity on the ventral surface of the nucleus. The medial margin of the nucleus is marked by the free edges of some of the constituent laminæ separated from one another by grooves. The main dimensions of the lateral geniculate body from which the model was constructed were as follows: Antero-posterior diameter (excluding the pregeniculate nucleus) $8.35 \mathrm{~mm}$., maximum breadth $5.0 \mathrm{~mm}$., maximum height $4.5 \mathrm{~mm}$.

In summary, the nucleus is a concavo-convex body with the dorsal surface convex medially and concave laterally, and the ventral surface correspondingly concave medially and convex laterally. This is related to the fact that, as can readily be seen in Fig. 3, in the main part of the nucleus medially the constituent lamin's are curved with a ventral concavity (everted), while laterally, in the lateral horn, they are convex ventrally (inverted). The salient surface features are : (1) the dorsal crest with its prominent, rounded posterior end marked by curving ridges and grooves ; (2) the medial tubercle ; (3) the rostral irregular part in relation to the entering optic tract ; and (4) the lateral horn.

A small elongated cellular mass, usually known as the: corpus pregeniculatum, appears within the lateral division of the optic tract before the oral pole of the main part of the lateral geniculate body makes its appearance in transverse sections. However, a number of specimens need to be studied before a definite conclusion is to be arrived at regarding the nature of this mass and its relation to the main nucleus. The cells are of the same type as those of the lateral geniculate body proper. The more ventrally situated cells are larger and more deeply stained than the others.

Laminar Organization.-The layers of the lateral geniculate body have been variously named by different investigators, but in this communication they will be referred to as layers $1,2,3,4,5$, and 6 , 
of which the ventral two large-celled layers are layers 1 and 2 and the four small-celled layers are $3,4,5$, and 6 from below upwards. The number of laminæ and their arrangement will be mentioned in the order of their appearance in serial sections from before backwards (see Fig. 1).

Half a millimetre from the oral pole layers 1 and 4 first become recognizable as two distinct layers, layer 1 as a thin, ventral, large-celled layer, and layer 4 as a thicker, dorsal, small-celled layer (Fig. 1a). A quarter of a millimetre further caudally, the layers 1,4 , and 5 become distinct (Fig. 1b). At a distance of $2.5 \mathrm{~mm}$. from the oral pole, the following laminar pattern is present : the layer 6 has now appeared and is seen arching over layer 5 , layers 4,5 , and 6 are not differentiated from each other at their lateral ends and layer 3 appears below and close to layer 4 (Fig. 1e). There is an irregular distribution of large cells near the ventral border of layer 3, while layer 1 shows its maximum ventral concavity at this level. Three millimetres from the oral pole all the six layers of the geniculate body are well defined. Layer 1 becomes more horizontal, and layer 2, though distinct, is not at this level separated from the layer 3 by a medullary lamina. Layers $3,4,5$, and 6 are distinct and separated from one another by medullary laminæ (Fig. 1g, h). Layers 4 and 6 unite at the medial and lateral extremities of the layer 5 and continue into the medial tubercle and lateral spur as a fused layer. At more caudal levels all six layers become well defined in the main segment of the nucleus, with interweaving medullary laminæ separating them. Composite laminæ formed by the fusion of layers 4 and 6 and of layers 3 and 5 , together with separate layers 2 and 1 , extend into the medial tubercle and lateral horn to constitute those parts of the geniculate body. In other words, these parts are typically composed of four laminx only, $1,2,3+5$, and $4+6$. Near the caudal pole (in sections taken transversely to the axis of the optic tract) the medial tubercle is absent, the six layers occupy the main part of the nucleus and appear relatively diminished in size, and in this region the laminar structure also becomes more complex. On the other hand the lateral horn maintains its four-layered character more or less throughout the antero-posterior extent of the geniculate body.

Numerical Data.-In order to determine the total number of cells in the lateral geniculate body and their distribution between the crossed and uncrossed laminæ and between large- and small-celled elements, the following procedure was adopted. The outlines of layer 1 , layer 2 , layers $4+6$, and layers $3+5$ were traced with a projection apparatus at a magnification of 30 diameters. This was done in every fifth section in the first 20 sections, every tenth section in the next 120 sections, every twentieth section in the next 620 sections, and every fifth section in the last 80 sections. The areas enclosed by the outlines of the above laminæ were measured with a planimeter. By the numerical integration of the planimeter measurements, the following volumes were estimated :

$$
\begin{array}{llll}
\text { Layer 1 } & \ldots & \ldots & 0.0054 \mathrm{c.cm} . \\
\text { Layer 2 } & \ldots & \ldots & 0.0031 \mathrm{c.cm} \\
\text { Layer 4+6 } & \ldots & \ldots & 0.0289 \mathrm{c.cm} \\
\text { Layer 3+5 } & \ldots & \ldots & 0.0232 \mathrm{c.cm}
\end{array}
$$

Total volume of large-celled layers $\quad \ldots \quad 0.0085 \mathrm{c.cm}$. ", " $\quad$ ", small-celled layers $\quad \ldots \quad 0.0521 \mathrm{c.cm}$.

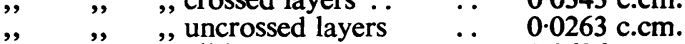

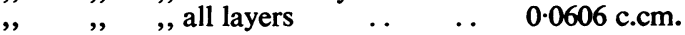

Next, the density of cells in the various layers was determined. The mean number of cells was estimated by counting the cells in 15 areas of 0.05 sq. $\mathrm{mm}$. taken at random in each layer. The thick-

\begin{tabular}{|c|c|c|c|c|c|}
\hline \multirow{2}{*}{ Large cells } & & & \multicolumn{3}{|c|}{ Density } \\
\hline & & & Crossed & & Uncrossed \\
\hline $\begin{array}{l}\text { Large cells } \\
\text { Small cells }\end{array}$ & - & 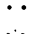 & $14 \cdot 1$ & - & $11 \cdot 6$ \\
\hline Section no & $10-135$ & $\because$ & $14 \cdot 2$ & . & $12 \cdot 1$ \\
\hline 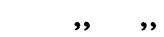 & $155-375$ & . & $19 \cdot \overline{8}$ & .. & $19 \cdot 2$ \\
\hline ," & $395-755$ & $\ldots$ & $22 \cdot 9$ & .. & $22 \cdot 1$ \\
\hline ," & $760-815$ & .. & $6 \cdot 5$ & $\therefore$ & $5 \cdot 8$ \\
\hline
\end{tabular}
ness of the sections was $10 \mu$, and the cell density was calculated in millions per c.cm. The results are as follows :

The total number of cells was estimated by multiplying the densities by the volumes of corresponding portions of the geniculate body. The results are :

\begin{tabular}{ccccc} 
& & \multicolumn{3}{c}{ Total cells in thousands } \\
& & Large & Small & Total \\
cells & cells & \\
Crossed layers & $\ldots$ & $75 \pm 2 \cdot 4$ & $612 \pm 9 \cdot 6$ & $687 \pm 10 \cdot 0$ \\
Uncrossed layers &.. & $36 \pm 1 \cdot 9$ & $487 \pm 9 \cdot 3$ & $523 \pm 9 \cdot 5$ \\
Total .. &.. & $111 \pm 3 \cdot 1$ & $1099 \pm 13 \cdot 4$ & $1210 \pm 13 \cdot 7$
\end{tabular}

The ratio between the volume of crossed and uncrossed layers is $34: 26$. The density of the cells is greater in crossed than in uncrossed layers, and the cell ratio between these two sets of layers is $56: 43$.

The number of large cells is about one-tenth that of the small cells, and it may be noted that the figures of Balado and Franke for Man show a proportion of between one-fifth and one-sixth, and those of Le Gros Clark for Macaca one-seventh to one-eighth.

The total number of small cells according to our estimate is of the order of $1,100,000$ and that of the large cells 110,000 , together making a total of about 1,210,000. Balado and Franke (1937) give an estimate of 482,664 of small cells and 86,181 large cells with a total of 568,845 . It is difficult to explain the discrepancy as the method which they used for their computation is not known. Taking into account the earlier estimates of the number of fibres in the human optic nerve (Zwanenburg, 440,000; 
K'appers, 550,000 ; and Krause, 400,000), they conclude that the number of cells corresponds to the number of optic fibres terminating in the geniculate body and that a $1: 1$ cell-fibre ratio, therefore, exists. A later computation by Bruesch and Arey (1940) shows that the number of optic fibres may vary from 564,776 to $1,140,030$. Arey and Bickel (1935) reported an average of 1,270,000 fibres in six optic nerves taken from individuals between 1 and 57 years of age. It may be mentioned that Krause's (1876) earlier estimate was $1,000,000$ and his second estimate, quoted by Balado and Franke, was really an estimate of the large or thick fibres. However, it may be noted that the range of variation in the estimates of the number of optic nerve fibres by the various observers appears to correspond with the range of variation in the estimates of the cell content of the geniculate body, as shown by our results and those of Balado and Franke. If the fibre-cell ratio is constant, an average of a $1: 1$ ratio may still hold good even for the extreme values.

Glees and Le Gros Clark (1941) reported that in the monkey the optic nerve fibres divide into 5 or 6 branches in the small-celled laminæ, implying a $1: 5$ or 6 ratio in those regions. If the $1: 1$ ratio applies to the geniculate body as a whole of this animal, then their further observation that no branching is seen in large-celled layers is significant and would mean a convergence of more than one optic fibre to a single large cell. In this connexion it may be mentioned that the 5 or 6 terminal branches were probably observed by these authors in the central vision area, and it is possible that the number of 'branches may be different in the peripheral vision area. It may also vary in the different laminæ.

The total laminar volume of the human geniculate body is estimated to be $60.6 \mathrm{c} . \mathrm{mm}$. The ratio of the volume of all the "crossed " layers to that of all the " uncrossed" layers is $343: 263$. On the other hand, the density of cells is slightly greater in the "crossed" laminæ. The ratio of the number of cells of the "crossed" large-celled layer to that of the "uncrossed" large-celled layer is $2: 1$, that for the small-cell layers being $5: 4$. The ratio of the total number of cells in both the " crossed " and " uncrossed" laminæ in the whole nucleus is $56: 43$ (or approximately $3: 2$ ). If the fibre-cell ratio is constant - for adjacent "crossed" and "uncrossed" laminæ, then this ratio would also apply to the crossed and uncrossed fibres of the optic tract terminating in the geniculate body. Previous estimates of the ratio of crossed and uncrossed fibres of the optic tract in man are those of Cajal (1899), $2: 1$, and Sántha (1932), $3: 2$. In Macaca, Le Gros Clark found the ratio to be $3: 2$.
The Projection of the Retina on the Human Lateral Geniculate Body

Experiments on monkeys have served to establish the general principle of a " point to point " projection of the retina on the lateral geniculate body in the higher Primates. The phrase "point to point " needs some modification in this connexion, as will be discussed below, but its general meaning is no doubt acceptable.

For the purpose of mapping the retinal projection areas in our reconstruction model of the human geniculate body, the available data based on experimental studies on the monkey's brain are not altogether applicable, for the details of the laminar pattern in Man and monkey are not entirely comparable. Recourse has therefore been had to reports on clinical cases of partial defects in the field of vision associated with localized secondary degeneration in the geniculate body. Unfortunately, detailed accounts of the extent and distribution of geniculate cell atrophy in such cases are relatively few, but those that are available provide important information. Rönne $(1910,1913)$ reported four cases of alcoholic amblyopia and two of diabetic amblyopia in which degeneration of the papillomacular bundle (with a central scotoma) was associated with localized areas of transneuronal degeneration in the geniculate body. His description of the extent of the localized geniculate atrophy is amplified by good microphotographs and excellent diagrams. In 1930, Brouwer reported a case of hemianopia with macular sparing to the extent of $12^{\circ}$ in the horizontal and $20^{\circ}$ in the vertical meridian (in a normal field, according to Traquair, the macular area of the retina covers a visual angle of $15^{\circ}$ to $20^{\circ}$ ). The evidence provided by the secondary degeneration in the geniculate body is complementary to that derived from Rönne's cases of amblyopia.* In 1914, Rönne reported a case of left-sided hemianopia in which macular sparing was not noticeable by perimetric tests but was just evident on a Bjerrum screen. The extent of the spared macular area amounted to about $1^{\circ}$ at the fixation point. In this critical case, thionin preparations of the right geniculate body showed severe cell degeneration, but normal cells were found in a small localized region in the caudal $2 \mathrm{~mm}$. of the nucleus (at which transverse level the degeneration affected only the lateral horn or "cauda"). The importance of this case is the evidence which it provides for the localization of the foveal centre in the lateral geniculate

* The writer has to thank Professor Brouwer for the opportunity of making a personal examination of the sections of the geniculate body from his case of hemianopia. A glass plate reconstruction was made in order to define accurately the extent of the degenerated area, made in order to define accurately the extent of the degenerated area, of the central and peripheral projection areas in the wax reconstruction model. 
body. In 1912, Winkler published the results of an anatomical study of two relevant cases of a mutually complementary nature. The first was a right lower homonymous hemianopia with the macula wholly affected in the right visual field and partly affected in the left. The other case was an upper homonymous hemianopia. A further case of a lower homonymous hemianopia was described by Polyak in 1942.

By reference to the basic data derived from the anatomical descriptions and diagrams in these clinical reports, it has been possible to plot the distribution and extent of the retinal projection areas in our reconstruction model in considerable detail (see Fig. 4). The main results of this study are as follows. The whole of the lateral horn of the lateral geniculate body constitutes the projection area for the lower peripheral quadrant of the retina, and it is interesting to note that, on the reconstruction model, a fairly distinct sulcus on the dorsal aspect of the geniculate body, and a less conspicuous groove on its ventral aspect, serve to mark externally the junction of the representation of the peripheral field of vision with that of the central field. The somewhat uneven region of the rostral third of the nucleus, together with the medial tubercle with which it is in continuity, comprises the whole projection area for the upper peripheral quadrant of the retina. The so-called "small inner segment" which is usually referred to, in transverse sections of the nucleus, as representing the upper peripheral quadrant is, in fact, only that part of this area comprised by the medial tubercle. On the ventral surface of the geniculate body the upper peripheral quadrant is demarcated from the central projection area by a groove, but on the dorsal aspect this functional boundary is not indicated by any external marking. The projection area for central vision has the form of an inverted pyramid with a convex base forming the arched elevation or crest on the dorsal aspect of the geniculate body, and a flattened apex ventrally. It is covered in front and over the rostral half of its medial aspect by the area for the upper peripheral visual field, and its lateral margin is related throughout its antero-posterior extent to the lower peripheral field area. The central projection area of the geniculate body is everywhere composed of six separate cell laminæ, the ventral large-celled layers 1 and 2, and the dorsal small-celled layers $3,4,5$, and 6 . Of these layers, as is now well established, 1, 4, and 6 receive crossed retinal fibres, and 2,3 , and 5 uncrossed fibres. In relation to the inverted pyramidal shape of the central visual field area, the relative extent of the several layers increases from the ventral to the dorsal aspect of the nucleus. Thus, the more dorsally situated layers are the more extensive, while the ventrally placed largecell layers make a relatively small contribution to the area. Moreover, this contribution of the largecell layers diminishes progressively towards the region representing the fixation point. In other words, there is a great preponderance of the smallcelled elements of the geniculate body in the area for central vision.

In general, the peripheral visual segments of the geniculate body present only four cell laminæ, the two large-celled layers 1 and 2, and two small-celled layers formed by the fusion of layers 3 and 5 , and layers 4 and 6. Moreover, in these segments there is a relatively greater preponderance of the largecelled elements than in the area for central vision. The laminar pattern in the projection area for upper peripheral vision, it should be noted, is not so uniform or regular as it is in the area for lower peripheral vision. This is at least partly due to the fact that the laminar arrangement is disrupted and disturbed by the entering fibres of the optic tract, but it remains possible that it may also be related to some functional difference.

If the geniculate body is viewed as a whole, it will be seen that a median antero-posterior section passing through the summit of the dorsal crest and the concavity of the ventral hilum divides the nucleus into halves which are asymmetrical in form but approximately equal in volume. The plane of such a section is the axial plane of the nucleus and represents the horizontal meridian of the retina; the rounded margin of the nucleus at the caudal end of the plane marks the site of projection of the foveal centre or fixation point, while the anterior end of the section represents the far peripheral point along the horizontal meridian of the retina. The posterior two-thirds of the dorsal crest of the geniculate body extends through the central visual field area, while its anterior third marks the boundary between the upper and lower peripheral visual field areas on either side. The vertical meridian of the retina is represented in the geniculate body by its irregular posterior border, extending from the caudal margin of the lateral horn to the back of the medial tubercle. On the other hand, the extreme peripheral margin of the sensitive retina corresponds to the irregular anterior margin of the nucleus.

From the foregoing description, it will be apparent that almost the whole of the human lateral geniculate body is concerned with binocular vision and contains an equal number of " crossed" and " uncrossed" cell laminæ. There is, however, a very small monocular area, represented by a narrow strip extending along the anterior margin of the nucleus (that part which corresponds to the extreme peripheral margin of the sensitive retina). This strip is 
distinguished in its intrinsic structure by the exclusion of " uncrossed" laminæ. It is composed only of two " crossed " laminæ, the large-celled layer 1, and a layer formed by the fusion anteriorly of the smallcelled layers 4 and 6 . These two " crossed "laminæe lose their identity to some extent and merge with each other at the extreme anterior margin of the nucleus.

It was mentioned above that the phrase " point to point," as used to describe the mode of projection of the retina on the lateral geniculate body, needs some qualification. In fact, each " point" in the retina appears to be projected on to a wedge-shaped sector of the nucleus, extending through its whole dorso-ventral thickness and composed of several cell laminæ. The nearer the retinal "point" is to the periphery of the retina, the shorter is the corresponding projection " wedge " in the geniculate body. Similarly, the meridians of the retina are represented in the nucleus not by lines, but by twodimensional planes of section. It is thus clear that, though the question of the fine and precise representation of the retina in the geniculate body was answered by the experiments of Le Gros Clark and Penman (1934) in a manner favourable to the concept of Henschen (1924), Willbrand (1897), and others, their phrase " point to point " must be taken to mean that each minute locus in the retina is actually projected on to a small circumscribed sector of definite dimensions in the geniculate body. If one could speak of a "visual unit" in the lateral geniculate body, it would be a pyramidal-shaped unit, to be compared with the parallelopipedon (Solnitzky and Harman, 1946) in the visual cortex.

\section{The Lateral Geniculate Body in Lower Primates}

Microcebus Murinus (Fig. 5).-A brief account of this nucleus has been previously given by Le Gros Clark (1931) in his study of the brain of Microcebus. Our reconstruction model shows that it is a somewhat lentiform body with a maximum vertical diameter of $2.7 \mathrm{~mm}$., a maximum width of $1.1 \mathrm{~mm}$., and an antero-posterior diameter of $2.79 \mathrm{~mm}$. The main mass of the body is prolonged forwards laterally into a prominent lip and converges behind to form a blunt posterior pole. The rostral lip forms the lateral boundary of a concavity which excavates the anterior surface of the nucleus as a whole. This deep concavity is occupied by the emerging fibres of the optic radiation. The medial aspect of the nucleus is separated by a low anteroposterior ridge into dorso-medial and ventro-medial surfaces, of which the former is in relation to the pulvinar and the latter to the medial geniculate body.

In its middle third, the geniculate body is composed of six fairly well defined cell laminæ. The two most superficial laminæ (1 and 2$)$ are composed $\bar{z}$ of large cells, and the remainder of small cells. The deeper laminæ (particularly lamina 6) are composed of densely packed cells and at their ventral ends show a tendency to crinkle into convolutions and to 0 become slightly everted. If the sections are traced of rostro-caudally, the small-celled layers increase gradually in number till all the layers become well defined in the middle third (see Fig. 5). More caudally they gradually disappear in a regular order from lamina 6 outwards. The laminæ are dorso- $\stackrel{5}{\rightarrow}$ ventrally disposed with a lateral convexity and a $\bar{O}$ medial concavity and thus show the typical lemuroid inversion pattern (Le Gros Clark, 1932).

The relative proportion of the large- and small- $\stackrel{\triangle}{2}$ celled elements appears to vary with the differentia- के tion of small-celled elements in different transverse $\vec{\circ}$ planes of the geniculate body. In the middle third, $\stackrel{-}{-}$ the small-celled elements predominate, and in the $\vec{\omega}$ caudal third the large-celled elements. The large-. celled layers extend over the whole of the convex lateral surface and also curve round the ventral ? border of the nucleus to reach the ventro-medial $\overrightarrow{\vec{H}}$ surface. They enter into the formation of the lattefi $\omega$ to an increasing extent towards the caudal end.

No data based on experimental work are availab for locating projection areas in lemurs. From the nature of the laminar organization of the monocules and binocular fields in the human geniculate bod 80 the rostral thinner part of the nucleus in Microcebus of may be considered as the monocular area where the. uncrossed laminæ are excluded. The main massive part forms the binocular area. From a comparative study of the projection areas in higher primates and lower mammals as worked out experimentally by Brouwer and others, it is possible to infer that the upper part of the nucleus is the projection field of the lower quadrant of the retina and vice versa.

Lemur Fulvus (Figs. 6 and 7). - The geniculate body of this lemur was included in a previous study by Woollard and Beattie (1927), but their description of it is short and incomplete. Our reconstruction model shows that it is a somewhat irregularly shaped structure, in which the maximum sagittal diameter and maximum width are both about $4.5 \mathrm{~mm}$. Its laminar pattern bears a general resemblance to that of Microcebus, but the laminæ are more elaborately $\frac{0}{3}$ folded. The constituent laminæ (as seen in transverse sections) present the inversion pattern, that is to say, they are curved in such a way that the deeper $\frac{\overrightarrow{ }}{0}$ small-celled laminæ are contained within the concavity formed by the superficial large-celled $N$ laminæ. The latter are curved in conformity with the convex surface of the thalamus. In the main $N$ part of the nucleus, however, the laminæ in the 
ventro-medial third become bent in the opposite direction so that here they appear everted. In other words, the laminar pattern in Lemur fulvus shows a combination of inversion and eversion, with a predominance of the former. There are four well-defined cell laminæ in this species, which comparative studies indicate are equivalent to laminæ 1, 2, 3, and 6 of Microcebus and other lemurs. But there is a relatively large space between laminæ 3 and 6 containing medium-sized and rather faintly staining cells scattered in diffuse formation. This indistinct mass of cells reaches its maximum crosssectional area in the middle third of the geniculate body and here shows a tendency to split into two ill-defined layers which evidently represent the cell laminæ 4 and 5 found in other lemurs. Thus, although only four laminæ are attributed to Lemur fulvus by Woollard and Beattie (1927), a total of six are potentially present. In the rostral half of the nucleus the small-celled elements preponderate, but in transverse sections through the caudal half the large-celled elements occupy a relatively greater area. As in Microcebus, the geniculate body of Lemur shows a general preponderance of the largecelled elements as compared with the higher Primates.

Macaca Mulatta (Fig. 8). - The reconstruction model of the macaque geniculate body has already been described by Le Gros Clark (1941). Its general appearance is well shown in Fig. 8, where the model is represented from its posterior aspect, cut horizontally through the middle, and the upper and lower halves separated from each other. The nucleus is somewhat pyramidal in shape, with a medially inclined apex above, and a hollowed-out base below. The basal concavity is continued upwards on to the postero-medial aspect of the body to form the " hilum," the sides of which are made up of the everted superficial large-celled lamina (lamina 1). The axis of the folding which forms the hilum corresponds to the junction of the four-layered anterior part of the geniculate body, and the sixlayered posterior part. These two parts, as demonstrated by the experimental work of Le Gros Clark and Penman, represent the peripheral and central fields of the retina respectively. Compared with the human and lemuroid types of nucleus, that of Macaca presents a completely everted pattern and also shows a somewhat different orientation with respect to the optic tract. The central vision area, which in the human geniculate body is situated posteriorly, in the monkey occupies rather the postero-superior region of the nucleus. Similarly, the monocular area, which in Man forms the rostral margin of the nucleus, is found at the ventral margin.
The complete eversion and the apparent rotation of the geniculate body in the monkey is probably related to the pressure of adjacent parts of the brain during development.

Factors which Determine the Form and Position of the Lateral Geniculate Body in the Primates

The relative position of the lateral geniculate body is determined largely by the growth and expansion of neighbouring elements of the thalamus. In primitive mammals, such as insectivores, the nucleus stretches throughout the antero-posterior extent of the lateral wall of the thalamus. With the expansion of the lateral nucleus of the thalamus it becomes first pushed caudally, and then displaced laterally and ventrally. With the ventral displacement there occurs a rotation of the geniculate body, so that the original dorsal and ventral poles become the lateral and ventral margins. These changes in position, with rotation, are to be observed in the Primate series. They account for the fact that, while in lower mammals the projection fields for upper and lower halves of the retina are represented in a reversed form in the lower and upper halves of the geniculate body, in the higher Primates they are represented respectively in the medial and lateral halves of the nucleus.

Intrinsic or functional factors and extrinsic or mechanical factors combine to explain the shape and laminar folding of the geniculate body. In the ascending series of Primates the functional factors are manifested, in the first place, by a relative increase in size of that region of the nucleus which is concerned with binocular vision. This region is proportionately thicker than the monocular region, for the latter, besides being less differentiated in its cellular architecture, includes "crossed" laminæ only. The introduction of a central vision area in the middle of the binocular region is the second functional factor. In the Primate series there is a progressive increase in the total number of small ganglion cells in the retina and especially their concentration in the central area of the retina, and this is correlated with a corresponding elaboration and expansion of the small-celled elements of the geniculate body. It is as a result of this expansion that the small-celled laminæ begin to extend beyond the limitations of the space which, in the inverted type of nucleus, is provided within the concavity of the large-celled elements, and assume a curve in the opposite direction so as to form a local eversion pattern. Although the lower Primates have no differentiated fovea centralis, a definite central vision area of the geniculate body is foreshadowed in the genus Microcebus, for even in this primitive Primate the deeper small-celled laminæ show a tendency to 
expand at their ventral end and to become everted. In Lemur this tendency becomes much more pronounced, and in the ventral third of the geniculate body of this genus the cell laminæ undergo a marked local eversion (in contrast to the inversion pattern of the rest of the nucleus). In Man the primitive inversion pattern is still retained in its original form as the lateral horn of the lateral geniculate body, which, as already noted, is concerned with peripheral vision. On the other hand, in the highly elaborated central vision area the laminæ are everted, forming a ventral concavity or "hilum" where branches of the anterior choroidal and posterior cerebral arteries form a particularly rich anastomosis before penetrating into the substance of the nucleus (Abbie, 1933 ; Balado and Franke, 1937). In the monkeys (both platyrrhine and catarrhine) the laminar pattern is entirely of the eversion type, that is, the superficial large-celled laminæ are throughout their extent contained within the concavity of the deeper small-celled laminæ. The hilum of the geniculate body in these groups of Primates is directed ventrally at its rostral end and postero-medially in the rest of the nucleus. As already noted, the completeness of the laminar eversion in the monkeys is no doubt partly due to the expansion of the central vision area of the small-celled elements, but it is evidently also conditioned by mechanical factors, for example, the pressure of adjacent parts of the brain in relation to the proportionately large size of the nucleus itself.

The regional variations in the laminar pattern of the geniculate body in Primates are determined initially by an increase in the relative proportion of uncrossed fibres in the optic tract, which leads to the progressive differentiation of " uncrossed" cell laminæ in the central vision area. In the monocular area of the higher Primates two cell laminæ are usually found, both related to the contralateral eye ; in the rest of the area for peripheral vision there are two sets of two laminæ, the two sets being related to the two eyes; and in the central vision area there are also two sets, but here, in general, each consists of three laminæ. In the lower Primates the laminar pattern is somewhat variable, and it is not by any means certain that the small-celled layers in the lemuroid geniculate body can be homologized severally with those found in the Anthropoidea. In the New World monkeys, the lamination of the small-celled elements may be indistinct, and in some cases (as in the marmoset) each set consists of two layers, only.

The differentiation of magnocellular and parvicellular types of laminæ appears to be characteristic of all the Primates, with the single exception of Tarsius, in which all the layers of the geniculate body are composed of cells of approximately similar size.
In the higher Primates, the large-celled layers are relatively reduced in the central-vision area of the geniculate body (probably because they are related to the rod. rather than the cone elements of the retina). In the lemurs, the large-celled elements show no such regional distribution - they are equally obtrusive over all fields of the geniculate body.

\section{Summary}

1. Wax reconstruction models of the lateral geniculate body of Man, Macaca, Lemur, and Microcebus have been prepared and, on the basis of these, the laminar pattern described in each form.

2. The variations of the laminar pattern in relation to monocular, peripheral, and central fields of the retina have been defined.

3. Numerical data regarding the volume and cell content of the different laminæ in the human geniculate body have been obtained, from which it is estimated that in Man the relation of crossed to uncrossed fibres in the optic tract is approximately $3: 2$.

4. The factors determining the form and position of the lateral geniculate body in the Primates have been discussed.

I gratefully acknowledge the active help given bi Professor Le Gros Clark in the preparation of this papero I am indebted to him for suggesting the line of research for providing the facilities, and for supervising the study? I wish also to thank Mr. D. J. Finney for assistance with
the numerical computations, and Miss M. F. Collinson for preparation of the illustrations.

\section{REFERENCES}

Abbie, A. A. (1933). J. Anat., Lond., 67, 491.

Arey, L. B., and Bickel, W. H., (1935). Anat. Rec., 61, (Suppl.), 3. (Quoted by Bruesch and Arey.)

Balado, M., and Franke, E. (1937). "Das Corpus Geniculatum Externum.” J. Springer. Berlin.

Brouwer, B. (1930). J. Psychol. Neurol., Lpz., 40, 147.

-, and Zeeman, W. P. C. (1925). J. Neurol. Psychopathol., 6, 1 .

$\longrightarrow$, (1926). Brain, 49, 1.

Bruesch, S. L., and Arey, L. B. (1940). J. Comp. Neurol., 631.

Cajal, S. R. (1899). "Die Struktur des Chiasma Opticum." Leipzig. (Quoted by Rogalsky.)

Clark, W. E. Le Gros (1931). Proc.Zool. Soc. London, 30, 413.

_(1932). Brit. J. Ophthal., 16, 264.

(1941). J. Anat., Lond., 75, 419.

(1942). Trans. ophth. Soc. U.K., 62, 229.

, and Penman, G. (1934). Proc. roy. Soc., B, 114, 229.

Glees, P., and Clark, W. E. Le Gros (1941). J. Anat., Lond., 75, 295.

Henschen, S. E. (1924). Scand. Scient. Rev., 3, 10. (Quoted by Putnam.) 
Kappers, C. U. A. (Quoted by Balado and Franke.) Krause, W. (1876). "Handbuch des Menschlichen Anatomie," Bd. 1, Hahn. Hanover. (Quoted by Bruesch and Arey.)

Monakow, C. von (1905). "Gehirn Pathologie, II." Vienna.

Polyak, S. L. (1942). J. Mt. Sinai Hosp., 9, 698.

Rogalski, T. (1946). J. Anat., Lond., 80, 153.

Rönne, H. (1910). Arch. Ophthal., Chicago, 77, 1. (1913). Ibid., 85, 489.

-(1914). Z. ges. Neurol. Psychiat., 22, 469.

-_(1914). Klin. Monatsbl. Augenheilk., 18, 470.

Sántha, K. (1932). V. Graef-Arch. Ophthal., 129, 224.
Solnitzky, O., and Harman, P. J. (1946). J. comp. Neurol., 85, 313.

Thuma, B. D. (1928). Ibid., 46, 173.

Willbrand, H. (1897). Klin. Mbl. Augenheilk., (Quoted by Rönne.)

Winkler, C. (1913). Kon. Akad. U. Wetensch te Amsterdam. Prol. Sect. Sc., 15, Pt. 2, 840. -(1918-1921). "Anatomie dens systeme nerveux." E. F. Bohn. Haarlem.

Woollard, H. H., and Beattie, J. (1927). J. Anat., Lond., $61,414$.

Zwanenburg, S. (1915). Inaug. Diss. Amsterdam. Quoted by Bruesch and Arey.) 


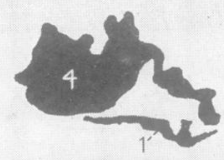

a
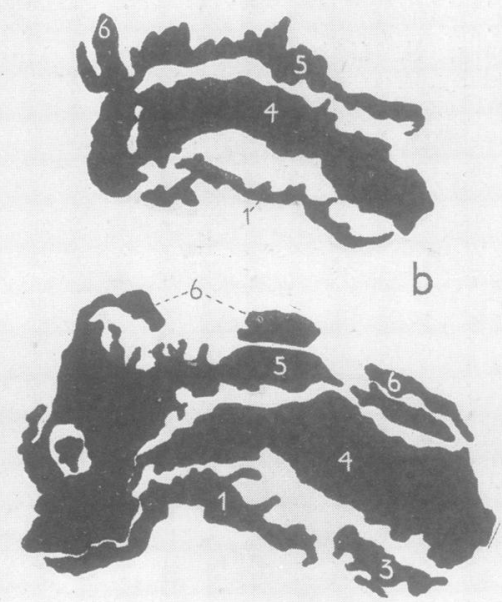

C


Fig. 1.-Tracings of the cell laminæ of the human lateral geniculate body made at intervals from serial transverse sections in a cranio-caudal direction. The lateral margin of the nucleus is to the left. The distances in millimetres of each section from the oral pole of the nucleus are as follows : $(a) 0.5 ;(b) 1.25 ;(c) 1.85$; $(d) 2.15 ;(e) 2.85 ;(f) 3.65 ;(g) 4.35 ;(h) 5.00 ;(i) 6.4$. Magnification +10 . 


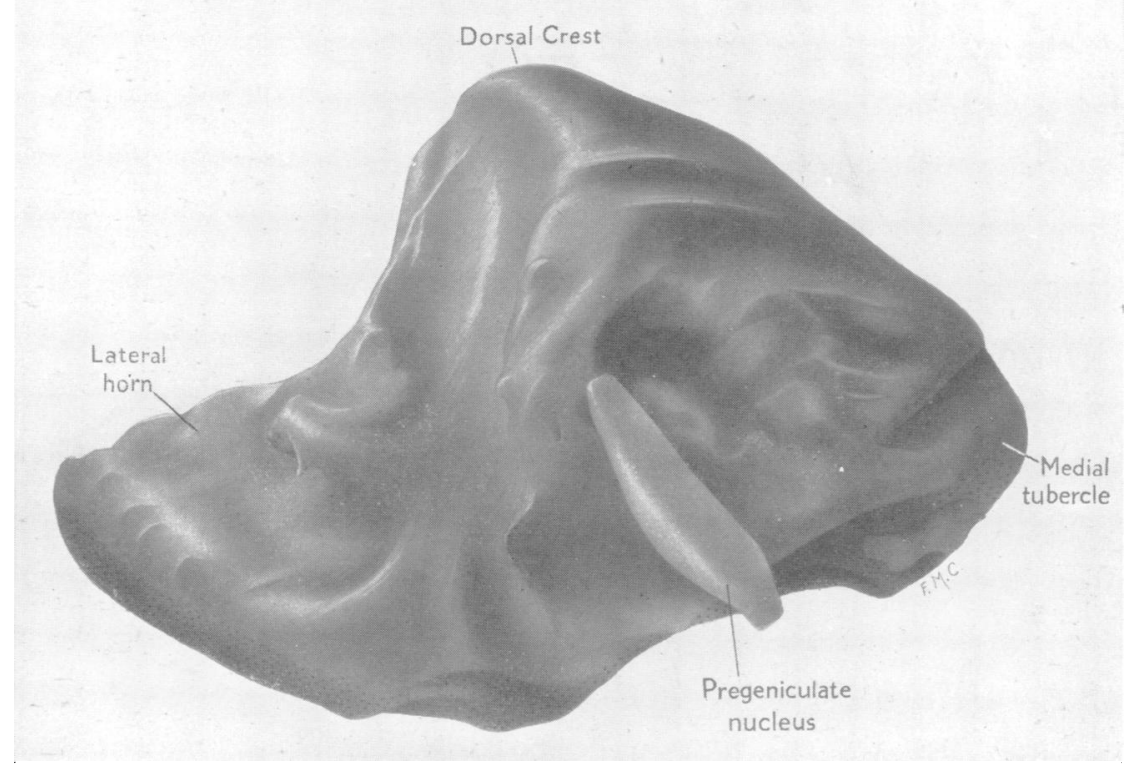

Fig. 2.-Reconstruction model of the right lateral geniculate body of a human brain, viewed from its anterior aspect. In this and other illustrations of reconstruction models, the position of the large-celled laminæ is marked with stippling.

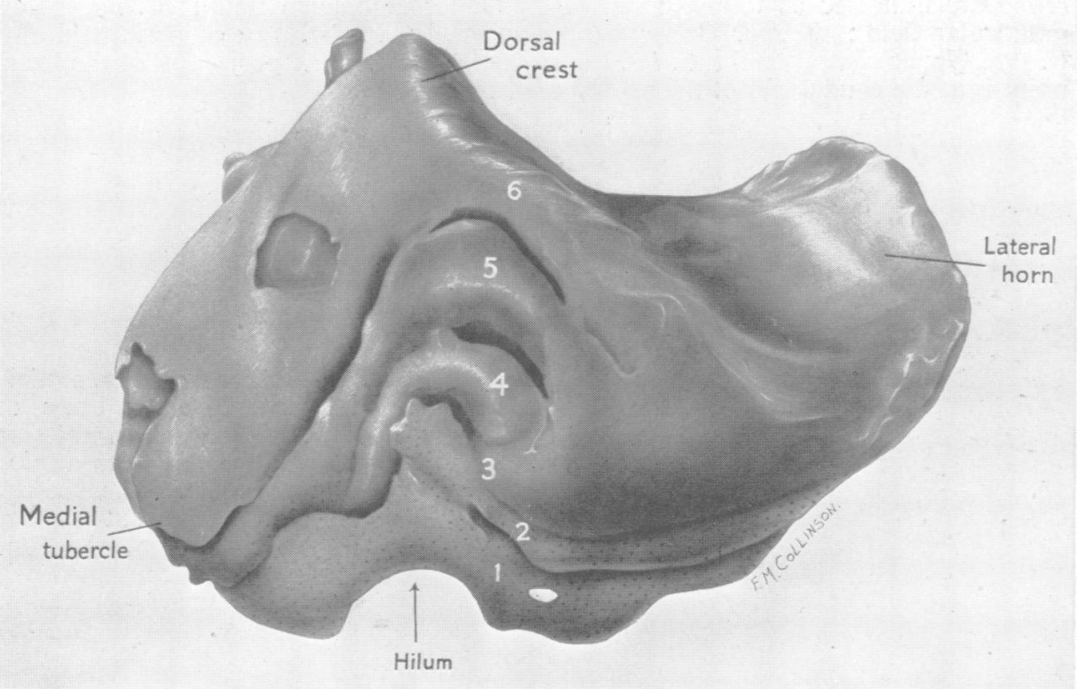

FIG. 3.-Reconstruction model of the right lateral geniculate body of a human brain, viewed from its posterior aspect. The arching of the cell laminæ to form an eversion-pattern in the main part of the nucleus is very evident. It is this arching which leads to the formation of a ventral hilum. The six cell laminæ are numbered in a ventro-dorsal direction. 


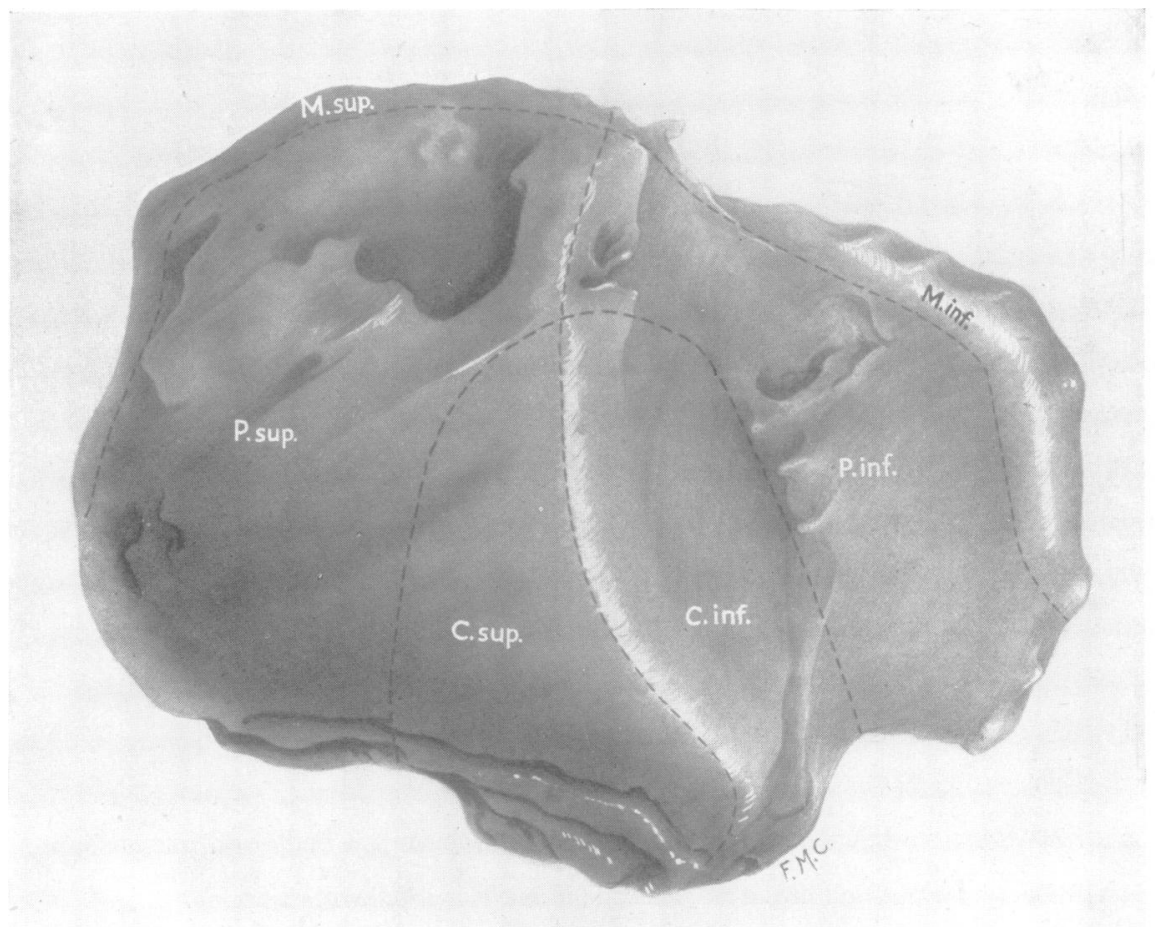

FIG. 4.-Reconstruction model of the right lateral geniculate body of a human brain, viewed from its dorsal aspect. The projection areas of the different fields of the retina are indicated as follows: $M$. sup. Upper monocular field; $M$. inf. Lower monocular field; $P$. sup. Upper peripheral field ; $P$. inf. Lower peripheral field ; $C$. sup. Upper central field ; C. inf. Lower central field. The projection of the fixation point is at the caudal end of the central areas.

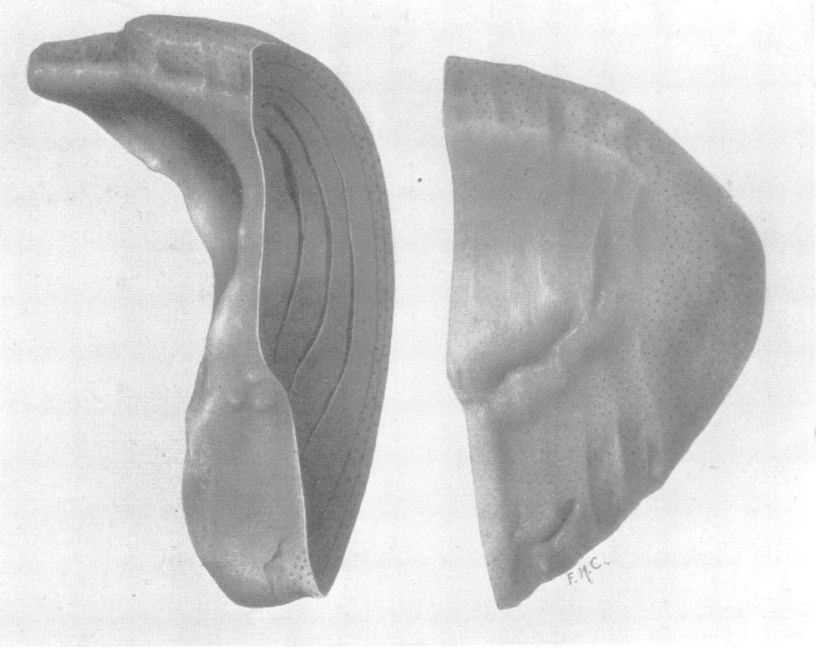

FIG. 5.-Reconstruction model of the right lateral geniculate body of Microcebus murinus, viewed from its medial aspect. The model has been sectioned coronally at its middle. The six cell laminæ are shown in the cut surface. Note the inversion pattern, the four small-celled laminæ being contained within the concavity of the superficially placed large cell laminæ. 


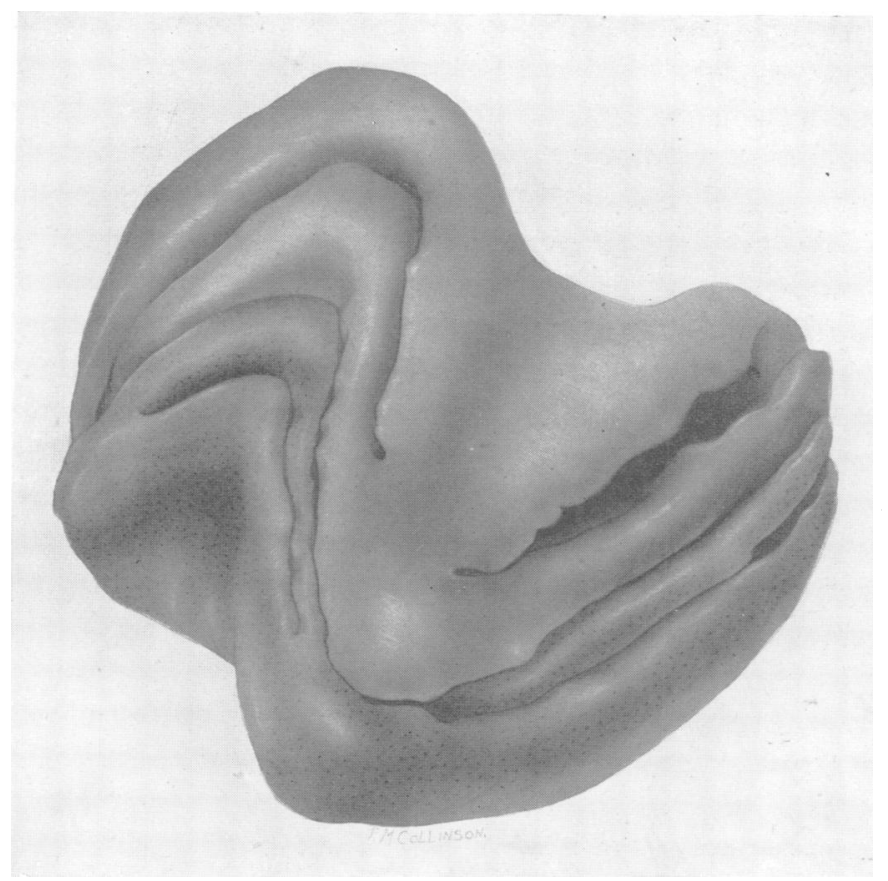

FIG. 6.-Reconstruction model of the right lateral geniculate body of Lemur fulvus, viewed from its postero-medial aspect. Four cell laminæ are seen, disposed laterally in an inversion pattern and medio-ventrally in an eversion pattern. The latter leads to the formation ventrally of a shallow hilum.

Fig. 7.-The caudal half of the reconstruction model of Lemur fulvus seen from in front. At this transverse level the laminæ are predominantly inverted, the two large-celled laminæ being superficial. The ventral extremities of the smallcelled laminæ are everted.

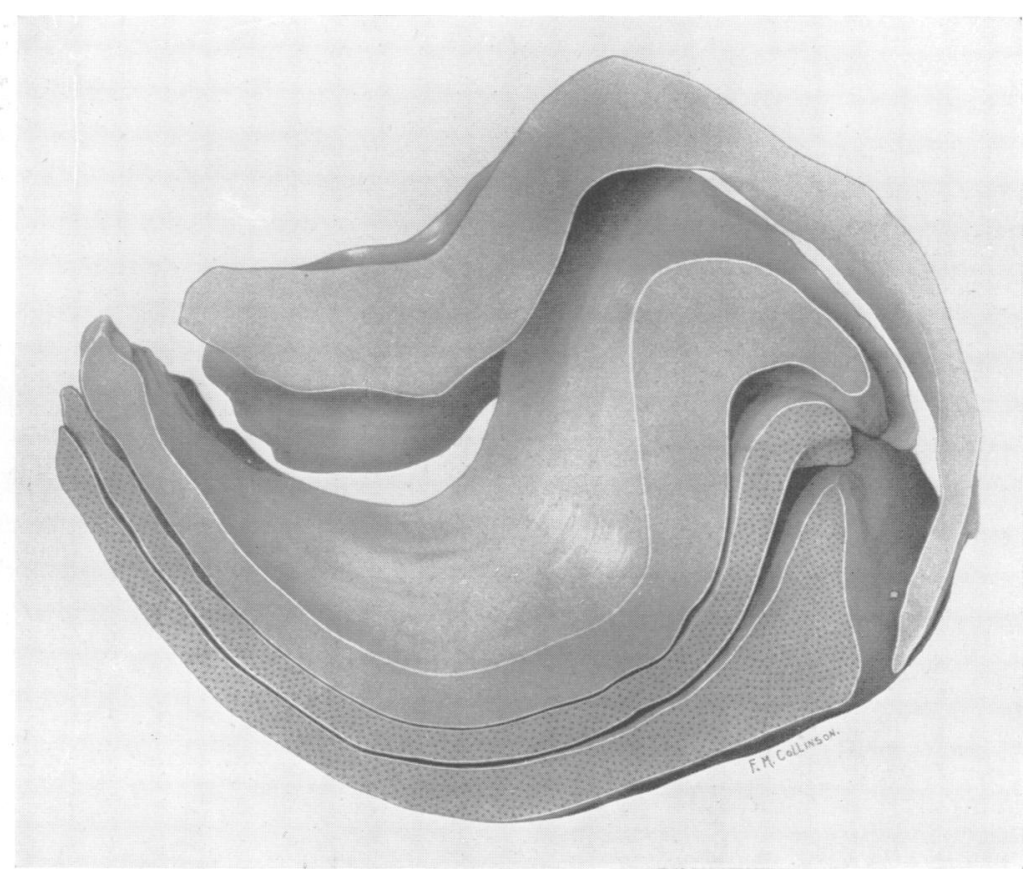


FIG. 8.-Reconstruction model of the left lateral geniculate body of Macaca mulatta, viewed from the posterior aspect. The model has been sectioned transversely at its middle. In the plane of section, the six-laminæ pattern is found in the caudal half of the nucleus, the rostral half being composed of four laminæ only. Note that the laminæ are completely everted, the superficial large-celled layers being contained within the concavity of the deeper small-celled layers. 